\title{
2 Canopy Fruit Location Can Affect Olive Oil Quality in 'Arbequina' Hedgerow Orchards
}

\author{
4 María Gómez del Campo • José M. García
}

5 Received: 14 January 2011/Revised: 21 June 2011/Accepted: 29 June 2011

6 (c) AOCS 2011

7 Abstract The effect of location of fruit in canopies of 8 hedgerow olive trees (Olea europaea L., cv. 'Arbequina') 9 on quality of virgin oil was tested by analyzing oils 10 extracted from different height layers and faces of nine 11 olive hedgerows (6 North-South oriented and 3 East12 West). Although sensory attributes were not different, other 13 oil quality parameters may be significantly modified by 14 fruit position. Oils extracted from fruits harvested from 15 higher layers exhibited significantly higher stability against 16 oxidation, along with higher palmitic acid, linoleic acid and 17 phenol contents, but lower oleic acid content. Oils extrac18 ted from fruits harvested from East and North facing 19 hedgerows oriented North-South and East-West, respec20 tively, exhibited higher oleic contents and lower saturated and polyunsaturated fatty acid contents. The mean phenol content of oils extracted from fruits from a North-South oriented hedgerow was significantly greater from one of the East-West oriented hedgerows. These findings may be relevant for the design of future olive hedgerows destined for olive oil production.

Keywords Virgin olive oil - Stability · Phenols . Fatty acid · Hedgerow design - Olea europaea

M. G. del Campo

Dpto. Producción Vegetal: Fitotecnia, Universidad Politécnica de Madrid, Ciudad Universitaria sn., 28040 Madrid, Spain e-mail: maria.gomezdelcampo@upm.es

\section{J. M. García ( $\bowtie)$}

Dpto. Fisiología y Tecnología de Productos Vegetales, Instituto de la Grasa (CSIC), Avda. Padre García Tejero, 4, 41012 Seville, Spain

e-mail: jmgarcia@cica.es

\section{Introduction}

The first studies with hedgerow or super-high-density orchards (714-1,975 olives/ha) were reported in Italy [1]. However, it was not until the 1990s that this production system was commercially adopted in Spain. Since then, it has spread rapidly worldwide, currently accounting for around 40,000 ha, and expanding at 10,000 ha per year. The objective of this system is to obtain high yields during early years of establishment from an orchard structure suited to mechanical pruning and harvesting. In these orchards, trees are usually pruned to a central leader and fruits are harvested with modified grape harvesters. Trees are trained into a hedgerow with characteristics that depend upon the harvester. Hedgerow height is frequently $1.7-3.0 \mathrm{~m}$ and hedgerow width between 1.0-2.0 $\mathrm{m}$. This canopy structure can be obtained with various tree spacings; $3 \times 1.35 \mathrm{~m}$ was used in the first commercial orchards but $4 \times 1.5 \mathrm{~m}$ is now more common.

Reports reveal how olive fruit characteristics are significantly modified according to their position in vaseshaped olive canopies [2]. In 'Arbequina' hedgerows, maturity and size were greater in upper layers while oil content increased by nearly $50 \%$ from lower to upper layers [3]. Some of these differences, such as fruit size and oil content, are strongly related to intercepted radiation $[4,5]$.

There are no published data on the effect of canopy position on oil fruit quality, although differences in other fruit characteristics indicate that possibility. Differences in maturity index and water content common in fruits harvested from different layers in hedgerows are likely associated with differences in oil quality [3]. Virgin oil extracted from ripe fruits (black skin) presents lower contents of natural antioxidants (tocopherols and phenols) than is obtained from immature olives (green skin) [6].

\section{1} 32 33 34 35 36 37 38 39 40 41 42 43

\begin{tabular}{|c|c|c|c|c|}
\hline 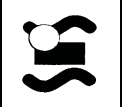 & $\begin{array}{l}\text { Journal : Large } 11746 \\
\text { Article No. : } 1900 \\
\text { MS Code : JAOCS-11-0028 }\end{array}$ & $\begin{array}{l}\text { Dispatch } \\
\square \quad \mathrm{LE} \\
\checkmark_{\mathrm{CP}}\end{array}$ & 14-7-2011 & $\begin{array}{l}\text { Pages : } \mathbf{1 1} \\
\square \text { TYPESET } \\
\checkmark \text { DISK }\end{array}$ \\
\hline
\end{tabular}


64 Since fruit growth and maturation is more rapid in upper 65 layers, differences in oil quality are also foreseeable.

66 Higher levels of intercepted radiation during grain (sun67 flower, soybean and maize) filling induce more oleic and 68 less linoleic and linolenic contents in the fatty acid 69 70 composition, thereby improving oil stability [7]. It seems likely, therefore, that fatty acid composition of oil should respond similarly to fruit location on olive hedgerows of various heights and orientations. Understanding of such responses would allow improved design of hedgerow structures and their management for optimum combinations of oil quantity and quality. Nine orchards from different locations were harvested layer by layer and oil was extracted and analyzed.

\section{Experimental Procedures}

The adult commercial hedgerows, all 'Arbequina', used in this study were oriented North-South (hedgerows A, B, C, D, E, F) and East-West (G, H, I). Hedgerows A, B, C, D, F, G, H were near El Carpio de Tajo-Toledo (39.9N), hedgerow E in Écija-Sevilla (37.5N) and Hedgerow I in Puebla de Montalbán-Toledo (39.5N).Their geometrical characteristics are shown in Table 1.

In each orchard, fruits were removed from nine individual trees separately in $1 \mathrm{~kg}$ samples from either side of the hedgerow and in layers according to height. Fruit were then combined by side and height into three groups (three trees each). Oil was extracted and analysed thus providing triplicate measurements for each combination of side and height in every orchard.

Samples were extracted separately and analysed using an Abencor analyzer (Comercial Abengoa S.A., Seville, Spain). This unit, consisting of three basic elements, a hammer mill, a thermobeater, and a pulp centrifuge, simulates the industrial process of virgin olive oil production on a laboratory scale [8]. Samples were crushed in a hammer mill (radius $47.5 \mathrm{~mm}$, with a sieve of $5.0 \mathrm{~mm}$ hole diameter) at $3,000 \mathrm{rpm}$. The resulting olive paste was placed into stainless steel 1-L containers and malaxated for $30 \mathrm{~min}$ in the thermobeater at $28^{\circ} \mathrm{C}$, using four stainless steel cross blades at $54.5 \mathrm{rpm}$ (radius $53 \mathrm{~mm}$ ). Subsequently, the paste was centrifuged in the pulp centrifuge for $1 \mathrm{~min}$ at 3,500 rpm (radius $100 \mathrm{~mm}$ ) to separate the liquid phase (oil and waste water) from the solid waste. Oil was then decanted into graduated tubes for the measurement of oil yield, then expressed as a percentage of the fresh weight taking $0.916 \mathrm{~kg} \mathrm{~L}^{-1}$ to be the density of olive oil at ambient temperature. After measurement, the oil was filtered through filter paper and stored in a $\mathrm{N}_{2}$ atmosphere at $-20{ }^{\circ} \mathrm{C}$ until analysis.

Free acidity, peroxide index value, and coefficients of specific extinction at 232 and $270 \mathrm{~nm}\left(K_{232}\right.$ and $\left.K_{270}\right)$ were evaluated according to the European Union Standard Methods [9]. Oxidative stability was measured by the Rancimat method, which evaluates the time (h) of resistance to oxidize a 3 -g oil sample exposed to a stream of dry air at a temperature of $100{ }^{\circ} \mathrm{C}[10]$.

Composition of fatty acids was determined by gas chromatographic analysis of the methyl esters. This was performed on a Varian Aerograph equipped with a flame ionization detector (FID), fitted with a column ( $2 \mathrm{~m}, 1 / 8 \mathrm{in}$. i.d.) packed with $12 \%$ EGS on a Chromosorb G, 80/100 mesh. The oven temperature was maintained at $185^{\circ} \mathrm{C}$ and the injector and detector at $225^{\circ} \mathrm{C}$. Flow rate of the $\mathrm{N}_{2}$ carrier gas was $30 \mathrm{~mL} / \mathrm{min}$ [11]. Data presented here are for the main fatty acids (carbon number:unsaturations): palmitic (16:0), palmitoleic (16:1), stearic (18:0), oleic (18:1), and linoleic (18:2). Other fatty acids including myristic (14:0), margaric (17:0), margaroleic (17:1), linolenic (18:3), arachidic (20:0), gadoleic (20:1) or behenic (22:0) were determined, but are not shown, because values were too small $(\leq 0.6 \%)$ for any significant role in oil quality. The following formulas using fatty acid content variables were calculated:

\begin{tabular}{|c|c|c|c|c|c|c|}
\hline $\begin{array}{l}\text { Table } 1 \text { Harvest date, row } \\
\text { orientation and canopy structure } \\
\text { of cv. 'Arbequina' hedgerows }\end{array}$ & Hedgerow & $\begin{array}{l}\text { Harvest date } \\
\text { (month/year) }\end{array}$ & $\begin{array}{l}\text { Hedgerow } \\
\text { orientation }\end{array}$ & $\begin{array}{l}\text { Tree } \\
\text { height }(\mathrm{m})\end{array}$ & $\begin{array}{l}\text { Row } \\
\text { spacing (m) }\end{array}$ & $\begin{array}{l}\text { Canopy } \\
\text { width }(\mathrm{m})\end{array}$ \\
\hline & A & $11 / 2006$ & North-South & 2.7 & 3.0 & 0.9 \\
\hline & B & $11 / 2007$ & North-South & 2.8 & 3.0 & 0.9 \\
\hline & $\mathrm{C}$ & $11 / 2006$ & North-South & 2.0 & 4.0 & 0.7 \\
\hline & $\mathrm{D}$ & $11 / 2007$ & North-South & 2.5 & 4.0 & 1.0 \\
\hline & E & $11 / 2007$ & North-South & 2.9 & 3.75 & 1.3 \\
\hline & $\mathrm{F}$ & $11 / 2008$ & North-South & 2.7 & 3.0 & 1.1 \\
\hline & G & $11 / 2006$ & East-West & 2.2 & 4.0 & 1.0 \\
\hline & $\mathrm{H}$ & $11 / 2007$ & East-West & 2.5 & 4.0 & 1.1 \\
\hline & I & $11 / 2008$ & East-West & 2.8 & 4.0 & 1.1 \\
\hline
\end{tabular}

\begin{tabular}{|llll|} 
Journal : Large 11746 & Dispatch : 14-7-2011 & Pages : 11 \\
Article No. : 1900 & $\sim_{\mathrm{CP}}^{\text {LE }}$ & $\square$ TYPESET \\
\hline MS Code : JAOCS-11-0028 & & $\checkmark$ DISK \\
\hline
\end{tabular}


Oleic:linoleic ratio $=|18: 1| / 18: 2 \mid$

Saturated fatty acid $($ SAFA $)=|16: 0|+|17: 0|+|18: 0|$ $+|20: 0|+|22: 0|$

Monounsaturated fatty acid (MUFA) $=|16: 1|+|17: 1|$ $+|18: 1|+|20: 1|$

Polyunsaturated fatty acid $($ PUFA $)=|18: 2|+|18: 3|$

Unsaturated fatty acid $($ UNFA $)=|16: 1|+|17: 1|+$ $|18: 1|+|18: 2|+|18: 3|+|20: 1|$

\section{UNFA/SAFA}

\section{MUFA/PUFA}

Sensory analysis of each oil sample was carried out by six trained tasters. The main negative (fusty, musty, winey, rancid, and metallic) and positive (olive fruit, bitterness and pungent) sensory attributes of the olive oils were evaluated using a structured scale of six points, where " 0 ", means absolute absence of the attribute; " 1 ", just detected; " 2 ", weak intensity; "3", middle intensity; "4", strong intensity; and " 5 ", strongest possible intensity of the attribute. In addition, the tasters described sensory profiles of the oils according to the most characteristic attributes.

Tocopherol content of a selection of oil samples was measured by HPLC using the IUPAC method [12]. The phenolic fraction of the same samples was isolated by solid-phase extraction and analyzed by reversed-phase HPLC using a diode-array UV detector [13]. Quantification of phenolic compounds (except ferulic acid) was carried out at $280 \mathrm{~nm}$ using $p$-hydroxyphenylacetic acid as an internal standard, whereas that of flavones and ferulic acid was made at $335 \mathrm{~nm}$ using $o$-coumaric acid as an internal

Table 2 Oil quality parameters of oils extracted from olives harvested at different layers in North-South hedgerows and, consequently, presenting two faces with East-West orientation

\begin{tabular}{|c|c|c|c|c|c|c|c|c|c|}
\hline \multirow[b]{2}{*}{ Hedgerow } & \multirow{2}{*}{$\begin{array}{l}\text { Parameter } \\
\text { Face height }(\mathrm{m})\end{array}$} & \multicolumn{2}{|c|}{ Peroxide value } & \multicolumn{2}{|l|}{$K_{270}^{\mathrm{a}}$} & \multicolumn{2}{|l|}{$K_{232}^{\mathrm{b}}$} & \multicolumn{2}{|l|}{ Stability } \\
\hline & & East & West & East & West & East & West & East & West \\
\hline A & $2.0-2.8$ & $3.2^{\mathrm{d}}$ & 2.9 & 0.10 & 0.11 & 1.42 & 1.41 & 38.9 & 31.5 \\
\hline A & $1.2-2.0$ & 2.7 & 2.8 & 0.11 & 0.12 & 1.43 & 1.31 & 43.7 & 31.4 \\
\hline A & $0.4-1.2$ & 4.3 & 2.3 & 0.11 & 0.10 & 1.52 & 1.40 & 28.5 & 35.9 \\
\hline B & $2.0-2.8$ & 4.8 & 4.9 & 0.11 & 0. & 1.39 & 1.39 & 37.9 & 35.7 \\
\hline B & $1.2-2.0$ & 4.7 & 8.5 & 0.10 & 0.12 & 1.35 & 1.41 & 29.8 & 28.1 \\
\hline B & $0.4-1.2$ & 9.7 & 4.2 & 0.11 & 0.10 & 1.45 & 1.36 & 26.9 & 29.4 \\
\hline $\mathrm{C}$ & $1.5-2.0$ & 3.5 & 3.3 & 0.10 & 0.11 & 1.51 & 1.58 & 44.8 & 47.5 \\
\hline $\mathrm{C}$ & $1.0-1.5$ & 3.1 & 4.2 & 0.11 & 0.12 & 1.50 & 1.53 & 51.6 & 44.1 \\
\hline $\mathrm{C}$ & $0.5-1.0$ & 3.3 & 3.4 & 0.10 & 0.10 & 1.46 & 1.44 & 41.3 & 41.7 \\
\hline $\mathrm{D}$ & $1.5-2.0$ & 5.4 & 5.2 & 0.12 & 0.12 & $1.71 \mathrm{~b}$ & $1.70 \mathrm{~b}$ & 59.2 & 60.1 \\
\hline $\mathrm{D}$ & $1.0-1.5$ & 5.4 & 5.3 & 0.11 & 0.11 & $1.62 \mathrm{bc}$ & $1.84 \mathrm{a}$ & 54.9 & 56.2 \\
\hline $\mathrm{D}$ & $0.5-1.0$ & 5.5 & 5.1 & 0.10 & 0.11 & $1.59 \mathrm{bc}$ & $1.54 \mathrm{c}$ & 48.9 & 49.0 \\
\hline $\mathrm{D}$ & $<0.5^{\mathrm{c}}$ & 4.1 & & 0.11 & & $1.40 \mathrm{~d}$ & & 42.1 & \\
\hline E & $>2.2$ & 4.1 & 3.8 & 0.10 & 0.11 & 1.42 & 1.50 & $37.7 \mathrm{ab}$ & $41.9 \mathrm{a}$ \\
\hline $\mathrm{E}$ & $1.6-2.2$ & 4.1 & 3.1 & 0.12 & 0.10 & 1.44 & 1.41 & $35.2 \mathrm{bc}$ & $36.3 \mathrm{~b}$ \\
\hline $\mathrm{E}$ & $1.0-1.6$ & 3.1 & 3.0 & 0.11 & 0.12 & 1.37 & 1.37 & $30.9 \mathrm{~cd}$ & $29.1 \mathrm{~d}$ \\
\hline E & $0.4-1.0$ & 3.7 & 3.4 & 0.10 & 0.11 & 1.46 & 1.40 & $28.2 \mathrm{~d}$ & $26.6 \mathrm{~d}$ \\
\hline $\mathrm{F}$ & $>2.8^{\mathrm{c}}$ & $4.2 \mathrm{a}$ & 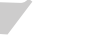 & $0.15 \mathrm{a}$ & & $1.56 \mathrm{a}$ & & $37.9 \mathrm{a}$ & \\
\hline $\mathrm{F}$ & $2.4-2.8$ & $3.4 \mathrm{bc}$ & $3.1 \mathrm{def}$ & $0.14 \mathrm{ab}$ & $0.14 \mathrm{ab}$ & $1.47 \mathrm{abc}$ & $1.47 \mathrm{abc}$ & $38.4 \mathrm{a}$ & $34.7 \mathrm{abc}$ \\
\hline $\mathrm{F}$ & $2.0-2.4$ & $3.8 \mathrm{ab}$ & $2.6 \mathrm{f}$ & $0.15 \mathrm{a}$ & $0.13 \mathrm{abc}$ & $1.43 \mathrm{abcd}$ & $1.43 \mathrm{abcd}$ & $35.6 \mathrm{ab}$ & $35.4 \mathrm{ab}$ \\
\hline $\mathrm{F}$ & $1.6-2.0$ & $3.9 \mathrm{at}$ & $4.2 \mathrm{a}$ & $0.12 \mathrm{bcd}$ & $0.13 a b c$ & 1.34 cde & 1.34 cde & $26.6 \mathrm{de}$ & $32.1 \mathrm{bc}$ \\
\hline $\mathrm{F}$ & $1.2-1.6$ & $3.3 \mathrm{cc}$ & $3.5 \mathrm{bcd}$ & $0.11 \mathrm{~cd}$ & $0.10 \mathrm{~d}$ & $1.24 \mathrm{efg}$ & $1.24 \mathrm{efg}$ & $29.5 \mathrm{~cd}$ & $30.0 \mathrm{~cd}$ \\
\hline $\mathrm{F}$ & $0.8-1.2$ & $3.0 \mathrm{de}$ & $4.1 \mathrm{a}$ & $0.10 \mathrm{~d}$ & $0.11 \mathrm{c} \mathrm{d}$ & $1.17 \mathrm{fg}$ & $1.17 \mathrm{fg}$ & $25.6 \mathrm{def}$ & $17.4 \mathrm{~g}$ \\
\hline $\mathrm{F}$ & $0.4-0.8$ & $2.9 \mathrm{ef}$ & 3.4 cde & $0.10 \mathrm{~d}$ & $0.10 \mathrm{~d}$ & $1.15 \mathrm{~g}$ & $1.15 \mathrm{~g}$ & $20.5 \mathrm{fg}$ & $23.5 \mathrm{ef}$ \\
\hline $\mathrm{F}$ & $<0.4^{\mathrm{c}}$ & $2.6 \mathrm{f}$ & & $0.10 \mathrm{~d}$ & & $1.26 \mathrm{efg}$ & & $20.6 \mathrm{fg}$ & \\
\hline
\end{tabular}

Each value is the mean value of three replicates

${ }^{\text {a }}$ Coefficient of specific extinction at $232 \mathrm{~nm}$

b Coefficient of specific extinction at $270 \mathrm{~nm}$

c In this layer the oil was extracted from the olives of both faces

d Two mean values of the same hedgerow followed by the same small letter are not significantly different $(P \leq 0.05)$ according to Duncan's multiple range test

\begin{tabular}{|l|lll|} 
Journal : Large 11746 & Dispatch : 14-7-2011 & Pages : 11 \\
Article No. : $\mathbf{1 9 0 0}$ & $\square \mathrm{LE}$ & $\square$ TYPESET \\
& MS Code : JAOCS-11-0028 & $\sim_{\mathrm{CP}}$ & $\checkmark$ DISK \\
\hline
\end{tabular}


Table 3 Oil quality parameters of oils extracted from olives harvested at different layers in East-West hedgerows and, consequently, presenting two faces oriented North-South

\begin{tabular}{|c|c|c|c|c|c|c|c|c|c|}
\hline \multirow[b]{2}{*}{ Hedgerow } & \multirow{2}{*}{$\begin{array}{l}\text { Parameter } \\
\text { Face height (m) }\end{array}$} & \multicolumn{2}{|c|}{ Peroxide value } & \multicolumn{2}{|l|}{$K_{270}^{\mathrm{a}}$} & \multicolumn{2}{|l|}{$K_{232}^{\mathrm{b}}$} & \multicolumn{2}{|l|}{ Stability } \\
\hline & & North & South & North & South & North & South & North & South \\
\hline G & $1.5-2.0$ & $3.2^{\mathrm{c}}$ & 3.1 & 0.11 & 0.11 & $1.53 \mathrm{ab}$ & $1.55 \mathrm{ab}$ & 45.3 & 41.2 \\
\hline G & $1.0-1.5$ & 3.6 & 3.4 & 0.09 & 0.10 & $1.47 \mathrm{~b}$ & $1.48 \mathrm{~b}$ & 39.5 & 38.7 \\
\hline G & $0.5-1.0$ & 3.3 & 3.9 & 0.09 & 0.09 & $1.46 \mathrm{~b}$ & $1.61 \mathrm{a}$ & 34.7 & 40.9 \\
\hline $\mathrm{H}$ & $1.5-2.0$ & 3.8 & 4.7 & 0.12 & 0.13 & 1.71 & 1.65 & 57.1 & 57.0 \\
\hline $\mathrm{H}$ & $1.0-1.5$ & 4.2 & 4.4 & 0.11 & 0.12 & 1.60 & 1.61 & 52.2 & 52.5 \\
\hline $\mathrm{H}$ & $0.5-1.0$ & 4.2 & 4.5 & 0.11 & 0.10 & 1.68 & 1.60 & 59.3 & 50.4 \\
\hline I & $>2.8$ & $4.9 a b c$ & $4.1 \mathrm{~cd}$ & $0.12 \mathrm{a}$ & $0.12 \mathrm{a}$ & $1.33 \mathrm{a}$ & $1.39 \mathrm{a}$ & $27.1 \mathrm{abc}$ & $30.8 \mathrm{a}$ \\
\hline I & $2.4-2.8$ & $3.5 \mathrm{de}$ & $3.0 \mathrm{e}$ & $0.11 \mathrm{ab}$ & $0.11 \mathrm{ab}$ & $1.34 \mathrm{a}$ & $1.23 \mathrm{bc}$ & $28.0 \mathrm{ab}$ & $27.8 \mathrm{ab}$ \\
\hline I & $2.0-2.4$ & $3.6 \mathrm{de}$ & $4.1 \mathrm{~cd}$ & $0.09 \mathrm{ab}$ & $0.09 \mathrm{ab}$ & $1.17 \mathrm{de}$ & $1.23 \mathrm{bc}$ & $21.0 \mathrm{bcd}$ & $21.6 \mathrm{bcd}$ \\
\hline I & $1.6-2.0$ & $4.4 \mathrm{bcd}$ & $4.3 \mathrm{bcd}$ & $0.09 \mathrm{ab}$ & $0.08 \mathrm{~b}$ & $1.13 \mathrm{e}$ & $1.17 \mathrm{de}$ & $24.3 \mathrm{abcd}$ & $24.5 \mathrm{abcd}$ \\
\hline I & $1.2-1.6$ & $5.1 a b c$ & $4.2 \mathrm{bcd}$ & $0.09 \mathrm{ab}$ & $0.08 \mathrm{~b}$ & $1.20 \mathrm{bcd}$ & $1.13 \mathrm{e}$ & $20.6 \mathrm{bcd}$ & $19.8 \mathrm{bcd}$ \\
\hline I & $0.8-1.2$ & $4.9 \mathrm{abc}$ & $5.5 \mathrm{a}$ & $0.08 \mathrm{~b}$ & $0.09 \mathrm{ab}$ & $1.10 \mathrm{e}$ & $1.24 b c$ & $20.2 \mathrm{bcd}$ & $18.0 \mathrm{~d}$ \\
\hline I & $0.4-0.8$ & $4.7 a b c$ & $5.2 \mathrm{ab}$ & $0.08 \mathrm{~b}$ & $0.08 \mathrm{~b}$ & $1.16 \mathrm{de}$ & $1.21 \mathrm{bcd}$ & $19.4 \mathrm{~cd}$ & $20.4 \mathrm{bcd}$ \\
\hline
\end{tabular}

Each value is the mean value of three replicates

${ }^{\text {a }}$ Coefficient of specific extinction at $232 \mathrm{~nm}$

${ }^{\mathrm{b}}$ Coefficient of specific extinction at $270 \mathrm{~nm}$

c Two mean values of the same hedgerow followed by the same small letter are not significantly different $(P<0.05)$ according to Duncan's multiple range test

standard. Data presented are ligstroside-aglycone di-aldehyde ( $p$-HPEA-EDA), oleuropein-aglycone mono-aldehyde (3,4 DHPA-EA), total flavones, total orthodiphenols, total secoiridoid derivatives and total phenolic compounds as proportion of oil content $\left(\mathrm{mg} \mathrm{kg}^{-1}\right)$ [13].

Data of each orchard were independently subjected to analysis of variance using MSTAT-C (University of Michigan, USA). Least significant differences $(P<0.05)$ were used to separate means of parameters evaluated between layers and sides of the hedgerows using Duncan's multiple range test. Furthermore, the effect of the side, respectively, in the different NS and EW hedgerows on the different fatty acid composition related variables was analyzed, pairing the values of each layer height, using three different statistical tests (Paired samples $t$ test, Wilcoxon signed ranks test, and Signs test). For testing, if the distribution of the frequencies of the special sensory attributes among the oils extracted was affected by the different canopy height layer or face from where the olives were harvested, analysis by $\chi^{2}$ in contingency tables was carried out. Data were globally analyzed by the mixed procedure of SAS (SAS Inst., Cary, NC).

\section{Results and Discussion}

Hedgerows A, B, C, and G presented no significant differences in most of the parameters evaluated, whereas hedgerows D, E, I and F did so. In a global analysis, all the quality parameters were significantly affected by hedgerow. These differences of behavior between hedgerows can be due to the different harvest dates, location or seasonal conditions of each one, when and where each respective sampling was carried out.

Parameters of Oil Quality

The values obtained by the extracted oils in the parameters legally established for evaluating the level of commercial quality (free acidity, peroxide value, $K_{232}$, and $K_{270}$ ) were, in all cases, inside the limits established for the commercial quality "extra", the best possible level of quality for virgin olive oils (Tables 2, 3). The free acidity reached very low values in all cases $(0.1-0.3 \%$ of oleic acid) and was not significantly affected by the fruit position in the canopy (data not shown). In contrast, in hedgerows I and F the values of $K_{232}, K_{270}$, and stability increased according to the height of the fruit growing layer, regardless of their orientation side. Furthermore, the oils extracted from the olives of hedgerows C, D and E showed a similar effect on $K_{232}$ (C and D) or stability against oxidation (E) values, whereas the rest of the oils were not affected. In a global analysis face and hedgerow orientation did not affect peroxides, $K_{232}, K_{270}$, and stability, but layer height significantly determined these parameters. In all of them the highest layer presented significantly higher values. The fact

\begin{tabular}{|llll|} 
Journal : Large 11746 & Dispatch : 14-7-2011 & Pages : 11 \\
Article No. : 1900 & $\square$ LE & $\square$ TYPESET \\
MS Code : JAOCS-11-0028 & $\checkmark_{\text {CP }}$ & $\checkmark$ DISK \\
\hline
\end{tabular}


Table 4 Fatty acid composition of the oils extracted from olives harvested at different layers in North-South hedgerows and, consequently, presenting two faces oriented East-West

\begin{tabular}{|c|c|c|c|c|c|c|c|c|c|c|c|}
\hline \multirow[t]{2}{*}{ Hedgerow } & \multirow{2}{*}{$\begin{array}{l}\text { Fatty acid } \\
\text { Face height }(\mathrm{m})\end{array}$} & \multicolumn{2}{|l|}{$16: 0$} & \multicolumn{2}{|l|}{$16: 1$} & \multicolumn{2}{|l|}{$18: 0$} & \multicolumn{2}{|l|}{ 18:1 } & \multicolumn{2}{|l|}{$18: 2$} \\
\hline & & East & West & East & West & East & West & East & West & East & West \\
\hline A & $2.0-2.8$ & $14.4^{\mathrm{a}}$ & 14.5 & 1.4 & 1.4 & 1.8 & 1.8 & 71.9 & 71.5 & 8.9 & 9.2 \\
\hline A & $1.2-2.0$ & 14.7 & 14.6 & 1.4 & 1.4 & 1.7 & 1.7 & 72.4 & 72.0 & 8.0 & 8.6 \\
\hline A & $0.4-1.2$ & 14.0 & 14.4 & 1.3 & 1.3 & 1.7 & 1.7 & 74.0 & 72.5 & 7.2 & 8.2 \\
\hline B & $2.0-2.8$ & 14.7 & 14.7 & 1.3 & 1.3 & 1.8 & 1.7 & 71.2 & 70.6 & 9.7 & 10.1 \\
\hline B & $1.2-2.0$ & 14.1 & 14.4 & 1.2 & 1.2 & 1.7 & 1.7 & 72.4 & 71.4 & 9.1 & 9.7 \\
\hline B & $0.4-1.2$ & 14.1 & 14.3 & 1.2 & 1.2 & 1.7 & 1.7 & 72.9 & 71.9 & 8.6 & 9.2 \\
\hline $\mathrm{C}$ & $1.5-2.0$ & 15.3 & 15.7 & 1.5 & 1.5 & 1.9 & 1.9 & 68.7 & 68.3 & 10.9 & 10.9 \\
\hline $\mathrm{C}$ & $1.0-1.5$ & 15.3 & 15.6 & 1.5 & 1.5 & 1.9 & 1.8 & 69.2 & 68.4 & 10.5 & 11.0 \\
\hline $\mathrm{C}$ & $0.5-1.0$ & 15.4 & 15.7 & 1.4 & 1.4 & 1.9 & 1.8 & 69.4 & 68.6 & 10.2 & 10.8 \\
\hline $\mathrm{D}$ & $1.5-2.0$ & $14.5 \mathrm{ab}$ & $14.9 \mathrm{a}$ & $1.4 \mathrm{a}$ & $1.4 \mathrm{a}$ & 2.2 & 2.3 & $71.1 \mathrm{~cd}$ & $70.4 \mathrm{~d}$ & $9.3 \mathrm{ab}$ & $9.6 \mathrm{a}$ \\
\hline $\mathrm{D}$ & $1.0-1.5$ & $14.1 \mathrm{bc}$ & $14.2 \mathrm{bc}$ & $1.3 \mathrm{ab}$ & $1.3 \mathrm{ab}$ & 2.2 & 2.2 & $72.4 \mathrm{~b}$ & $71.7 \mathrm{bc}$ & $8.6 \mathrm{~d}$ & $9.1 \mathrm{bc}$ \\
\hline $\mathrm{D}$ & $0.5-1.0$ & $13.6 \mathrm{c}$ & $13.7 \mathrm{c}$ & $1.2 \mathrm{~b}$ & $1.2 \mathrm{~b}$ & 2.2 & 2.2 & $73.2 \mathrm{a}$ & $72.3 \mathrm{~b}$ & $8.2 \mathrm{e}$ & $9.0 \mathrm{bcd}$ \\
\hline $\mathrm{D}$ & $<0.5^{\mathrm{b}}$ & $13.9 \mathrm{bc}$ & & $1.2 \mathrm{~b}$ & & 2.2 & & $72.5 \mathrm{ab}$ & & $8.8 \mathrm{~cd}$ & \\
\hline $\mathrm{E}$ & $>2.2$ & 17.9 & 16.6 & 1.8 & 1.9 & 1.8 & 1.8 & $66.0 \mathrm{bc}$ & $67.3 \mathrm{bc}$ & $10.8 \mathrm{~b}$ & $10.9 \mathrm{~b}$ \\
\hline $\mathrm{E}$ & $1.6-2.2$ & 17.0 & 19.0 & 1.9 & 1.7 & 1.8 & 1.8 & $67.3 \mathrm{bc}$ & $65.3 \mathrm{c}$ & $10.4 \mathrm{~b}$ & $10.6 \mathrm{~b}$ \\
\hline $\mathrm{E}$ & $1.0-1.6$ & 17.4 & 17.5 & 1.8 & 1.7 & 1.7 & 1.8 & $67.6 \mathrm{ab}$ & $66.7 \mathrm{bc}$ & $9.7 \mathrm{~b}$ & $10.7 \mathrm{~b}$ \\
\hline $\mathrm{E}$ & $0.4-1.0$ & 15.8 & 17.1 & 1.9 & 1.8 & 1.7 & 1.7 & $69.4 \mathrm{a}$ & $67.2 \mathrm{bc}$ & $14.2 \mathrm{a}$ & $10.5 \mathrm{~b}$ \\
\hline $\mathrm{F}$ & $>2.8^{\mathrm{b}}$ & $14.3 \mathrm{a}$ & & $1.4 \mathrm{a}$ & & 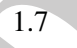 & & $71.6 \mathrm{~g}$ & & $9.3 \mathrm{a}$ & \\
\hline $\mathrm{F}$ & $2.4-2.8$ & $13.9 \mathrm{abc}$ & $14.1 \mathrm{ab}$ & $1.4 \mathrm{a}$ & $1.4 \mathrm{a}$ & 1.7 & 1.7 & $72.4 \mathrm{ef}$ & $71.8 \mathrm{fg}$ & $8.9 \mathrm{ab}$ & $9.2 \mathrm{a}$ \\
\hline $\mathrm{F}$ & $2.0-2.4$ & 13.7 abcd & 13.7 abcde & $1.3 \mathrm{~b}$ & $1.2 \mathrm{~b}$ & 1.7 & 1.8 & $72.8 \mathrm{cde}$ & $72.8 \mathrm{de}$ & $8.6 \mathrm{~b}$ & $8.8 \mathrm{~b}$ \\
\hline $\mathrm{F}$ & $1.6-2.0$ & $13.7 \mathrm{abcd}$ & 13.4 bcde & $1.2 \mathrm{bc}$ & 1.2 & 1.7 & 1.7 & $73.6 \mathrm{bc}$ & $73.4 \mathrm{~cd}$ & $8.0 \mathrm{c}$ & $8.5 \mathrm{~b}$ \\
\hline $\mathrm{F}$ & $1.2-1.6$ & 13.4 cde & 13.5 bcde & $1.1 \mathrm{cde}$ & 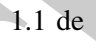 & 1.7 & 1.6 & $74.2 \mathrm{ab}$ & $73.4 \mathrm{~cd}$ & $7.8 \mathrm{c}$ & $8.5 \mathrm{~b}$ \\
\hline $\mathrm{F}$ & $0.8-1.2$ & $13.3 \mathrm{cde}$ & $13.0 \mathrm{e}$ & 1.1 cde & $1.0 \mathrm{e}$ & 1.6 & 1.6 & $74.5 \mathrm{a}$ & $73.5 \mathrm{bcd}$ & $7.7 \mathrm{c}$ & $8.8 \mathrm{~b}$ \\
\hline $\mathrm{F}$ & $0.4-0.8$ & $13.1 \mathrm{de}$ & $13.7 \mathrm{abcd}$ & $1.1 \mathrm{cde}$ & $1.0 \mathrm{e}$ & 1.6 & 1.7 & $74.7 \mathrm{a}$ & $73.9 \mathrm{bc}$ & $7.6 \mathrm{c}$ & $8.8 \mathrm{~b}$ \\
\hline $\mathrm{F}$ & $<0.4^{\mathrm{b}}$ & $13.2 \mathrm{cde}$ & & $1.0 \mathrm{e}$ & & 1.6 & & $74.4 \mathrm{a}$ & & $7.9 \mathrm{c}$ & \\
\hline
\end{tabular}

Each value is the mean value of three replicates

a Two mean values of the same hedgerow followed by the same small letter are not significantly $(P \leq 0.05)$ different according to Duncan's multiple range test

b In this layer the oil was extracted from the olives of both faces

of displaying simultaneously higher values of oxidation parameters and stability against oxidation, although seeming contradictory, can be explained by the simultaneously higher presence of linoleic acid, natural antioxidants and palmitic acid in the oil extracted from olives of the upper layers of the hedgerow. The values of $K_{232}$ are closely related to the presence of conjugated fatty acid in the oil. These acids are formed by the approach of the double bonds in the lineal carbon chain of the polyunsaturated fatty acids (linoleic and linolenic). This transformation is a step previous to the formation of fatty acid hydroperoxides and cannot be avoided by the antioxidants. García et al. [14] reported that the progress of the olive maturation level could determine a significant increase in the parameters used to evaluate the oxidative alteration of the virgin olive oils subsequently extracted from these fruits; as, recently, Gomez del Campo et al. [3] found that the fruits harvested from the higher canopy layer in an 'Arbequina' olive hedgerow showed a higher maturity level than the ones grown in the lower layers. It seems to be logical that the first ones produced oils with a higher level of oxidative alteration and lower time of oxidative stability. However, the activity of the olive cell enzymes (lipooxygenase, hydroperoxide lyase, etc.), which are responsible for these maturation linked oil alterations, probably depends on multiple seasonal factors (temperature, irrigation, fertilization, etc.). For this reason, this increase in oxidative parameter associated with fruit maturation is not a constant rule. Yousfi et al. [6] did not find any significant increase in oxidative oil alteration during 'Arbequina' and 'Picual' olive fruit maturation. That would explain the absence of the effect observed in some hedgerows. The

\begin{tabular}{|l|lll|}
\hline Journal : Large 11746 & Dispatch : 14-7-2011 & Pages : 11 \\
Article No. : 1900 & $\square$ LE & $\square$ TYPESET \\
MS Code : JAOCS-11-0028 & $\sim_{\text {CP }}$ & $\checkmark$ DISK \\
\hline
\end{tabular}


Table 5 Fatty acid composition of oils extracted from olives harvested at different layers in East-West hedgerows and, consequently, presenting two faces oriented North-South

\begin{tabular}{|c|c|c|c|c|c|c|c|c|c|c|c|}
\hline \multirow[b]{2}{*}{ Hedgerow } & \multirow{2}{*}{$\begin{array}{l}\text { Fatty acid } \\
\text { Face height }(\mathrm{m})\end{array}$} & \multicolumn{2}{|l|}{$16: 0$} & \multicolumn{2}{|l|}{ 16:1 } & \multicolumn{2}{|l|}{ 18:0 } & \multicolumn{2}{|l|}{$18: 1$} & \multicolumn{2}{|l|}{$18: 2$} \\
\hline & & North & South & North & South & North & South & North & South & North & South \\
\hline G & $1.5-2.0$ & $15.4^{\mathrm{a}}$ & 15.9 & 1.4 & 1.6 & 2.0 & 1.9 & 67.8 & 66.8 & 11.7 & 12.2 \\
\hline G & $1.0-1.5$ & 15.7 & 15.9 & 1.5 & 1.5 & 1.9 & 1.9 & 67.7 & 67.4 & 11.5 & 11.6 \\
\hline G & $0.5-1.0$ & 15.7 & 15.9 & 1.4 & 1.5 & 1.9 & 1.9 & 68.5 & 68.3 & 10.9 & 10.9 \\
\hline $\mathrm{H}$ & $1.5-2.0$ & 14.7 & 15.1 & 1.4 & 1.6 & 2.1 & 2.0 & 69.8 & 69.4 & 10.5 & 10.5 \\
\hline $\mathrm{H}$ & $1.0-1.5$ & 14.5 & 14.8 & 1.4 & 1.5 & 2.0 & 2.0 & 70.4 & 69.9 & 10.3 & 10.3 \\
\hline $\mathrm{H}$ & $0.5-1.0$ & 14.6 & 14.9 & 1.4 & 1.5 & 2.1 & 2.0 & 70.5 & 70.2 & 10.0 & 9.9 \\
\hline I & $>2.8$ & $12.8 \mathrm{ab}$ & $13.3 \mathrm{a}$ & $1.1 \mathrm{ab}$ & $1.2 \mathrm{a}$ & 1.7 & 1.7 & 74.4 ef & $73.3 \mathrm{f}$ & $8.3 \mathrm{ab}$ & $8.7 \mathrm{a}$ \\
\hline I & $2.4-2.8$ & $12.3 \mathrm{bc}$ & $13.0 \mathrm{a}$ & $1.0 \mathrm{ab}$ & $1.1 \mathrm{ab}$ & 1.7 & 1.7 & $75.1 \mathrm{de}$ & $74.2 \mathrm{ef}$ & $8.1 \mathrm{~b}$ & $8.2 \mathrm{~b}$ \\
\hline I & $2.0-2.4$ & $12.3 \mathrm{bc}$ & $12.2 \mathrm{bcd}$ & $1.0 \mathrm{ab}$ & $1.0 \mathrm{ab}$ & 1.7 & 1.7 & $75.7 \mathrm{~cd}$ & $75.7 \mathrm{~cd}$ & $7.5 \mathrm{~cd}$ & $7.6 \mathrm{~cd}$ \\
\hline I & $1.6-2.0$ & $11.6 \mathrm{cde}$ & 11.8 cde & $0.9 \mathrm{~b}$ & $0.9 \mathrm{~b}$ & 1.7 & 1.7 & $77.0 \mathrm{ab}$ & $76.5 \mathrm{bc}$ & $7.0 \mathrm{e}$ & $7.2 \mathrm{de}$ \\
\hline I & $1.2-1.6$ & $11.4 \mathrm{e}$ & $12.0 \mathrm{cde}$ & $0.8 \mathrm{~b}$ & $1.0 \mathrm{ab}$ & 1.7 & 1.6 & $77.8 \mathrm{ab}$ & $76.7 \mathrm{bc}$ & $6.5 \mathrm{fg}$ & 6.9 ef \\
\hline I & $0.8-1.2$ & $11.3 \mathrm{e}$ & $11.8 \mathrm{cde}$ & $0.8 \mathrm{~b}$ & $0.9 \mathrm{~b}$ & 1.6 & 1.6 & $78.2 \mathrm{a}$ & $77.1 \mathrm{ab}$ & $6.3 \mathrm{~g}$ & 6.8 ef \\
\hline
\end{tabular}

Each value is the mean value of three replicates

a Two mean values of the same hedgerow followed by the same small letter are not significantly different $(P \leq 0.05)$ according to Duncan's multiple range test

peroxide values in hedgerows I and $\mathrm{F}$ showed an erratic behavior, without a logical ranking according to height layers. This fact should be due to the dependence of this variable on handling during the process of extraction. A higher exposure of the oil to an air atmosphere due to a delay during this process may induce small differences in this parameter that may reach statistical significance, if the values are in general low, as they are in this case.

\section{Fatty Acid Composition}

Fatty acids such as myristic, margaric, margaroleic, araquic, gadoleic and behenic presented very low concentrations $(<0.5 \%)$ in all the oils and were not considered in this study (data not shown). In the same way, the linolenic acid (18:3) concentration of all the oils varied in a close range between 0.5 and $0.7 \%$ without showing any significant difference due to the position of the fruit in the tree from where it was extracted, which is why it was not considered either. Hedgerows named as A, B, C, G, and $\mathrm{H}$ did not show any effect of the fruit position in the different canopy height layers on the fatty acid composition of the oils extracted (Tables 4, 5). However, the fatty acid composition of the oils extracted from olives grown in D, E, F, and I hedgerows were significantly affected by this factor. In these hedgerows, the concentration of oleic decreases according to the height layer increase, whereas the concentrations of the other fatty acids (palmitic, palmitoleic, stearic and linoleic) shows an inverse tendency. These results were confirmed in a global analysis: oleic was significantly higher in the lower layers but palmitic, palmitoleic, stearic an linoleic were significantly higher in the upper layers. This fact could be related to the higher maturity level of the olives harvested from the upper canopy layers previously observed [3]. Different authors have found that the increase in olive maturation level coincided with a significant increase in the presence of linoleic acid in the oils [15-17]. Probably, the higher quantity of solar energy received by the upper canopy layers was used by the olive cells for increasing the fatty acid synthesis in general and, specifically, for the microsomal oleic acid desaturation action to form linoleic acid. For this reason, the olives harvested from these more illuminated canopy layers had higher fat contents [3] and the oils extracted showed higher percentages of SAFA and linoleic acid and lower percentages of oleic acid. In a global analysis face significantly modified fatty acid composition, East face had more oleic content than West, but palmitoleic and linoleic were higher in the West face.

The different height layer of the fruit in the canopy of some olive hedgerow displayed a significant effect on the variables constituted by formulas calculated with different fatty acid contents (Tables 6, 7). Thus, the oleic: linoleic ratio (18:1/18:2) proved to be significantly affected by this factor in hedgerows C, D, F, and I, showing a coherent tendency according to the variability observed separately in their components. This ratio increased in the lower canopy layers and decreased in the higher ones, coinciding with the inverse variation observed in the contents of oleic and linoleic acids, respectively. In the same way, the variation of the MUFA content, where oleic acid content is the determinant value, or the variation of the MUFA/PUFA

\begin{tabular}{|l|lll|}
\hline & Journal : Large 11746 & Dispatch : 14-7-2011 & Pages : 11 \\
Article No. : $\mathbf{1 9 0 0}$ & $\square_{\mathrm{CP}}^{\mathrm{LE}}$ & $\square$ \\
MS Code : JAOCS-11-0028 & $\cup_{\mathrm{CP}}^{\text {TYPESET }}$ \\
\hline
\end{tabular}


Table 6 Fatty acid formulas of the oils extracted from olives harvested at different height layers in North-South hedgerows and, consequently presenting two faces oriented East-West

\begin{tabular}{|c|c|c|c|c|c|c|c|c|c|c|c|c|c|}
\hline \multicolumn{2}{|c|}{ Fatty acid formula } & \multicolumn{2}{|c|}{$18: 1 / 18: 2^{a}$} & \multicolumn{2}{|l|}{ SAFA $^{b}$} & \multicolumn{2}{|l|}{ MUFA $^{\mathrm{c}}$} & \multicolumn{2}{|l|}{$\mathrm{PUFA}^{\mathrm{d}}$} & \multicolumn{2}{|c|}{$\mathrm{UNFA}^{\mathrm{e}} / \mathrm{SAFA}$} & \multicolumn{2}{|c|}{ MUFA/PUFA } \\
\hline Hedgerow & $\begin{array}{l}\text { Face } \\
\text { height }(\mathrm{m})\end{array}$ & East & West & East & West & East & West & East & West & East & West & East & West \\
\hline A & $2.0-2.8$ & $8.1^{\mathrm{f}}$ & 7.8 & 16.8 & 16.8 & 73.9 & 73.5 & 9.6 & 9.8 & 5.0 & 5.0 & 7.8 & 7.5 \\
\hline A & $1.2-2.0$ & 9.1 & 8.5 & 17.0 & 16.9 & 74.5 & 74.0 & 8.7 & 9.3 & 4.9 & 4.9 & 8.6 & 8.0 \\
\hline A & $0.4-1.2$ & 10.3 & 9.0 & 16.3 & 16.7 & 76.0 & 74.6 & 7.8 & 8.9 & 5.2 & 5.0 & 9.8 & 8.5 \\
\hline B & $2.0-2.8$ & 7.4 & 7.0 & 16.9 & 16.9 & 72.9 & 72.5 & 10.2 & 10.7 & 4.9 & 4.9 & 7.2 & 6.8 \\
\hline B & $1.2-2.0$ & 8.0 & 7.4 & 16.4 & 16.7 & 74.1 & 73.2 & 9.6 & 10.3 & 5.1 & 5.0 & 7.7 & 7.2 \\
\hline B & $0.4-1.2$ & 8.5 & 7.8 & 16.3 & 16.5 & 74.7 & 73.7 & 9.1 & 9.8 & 5.1 & 5.1 & 8.2 & 7.5 \\
\hline $\mathrm{C}$ & $1.5-2.0$ & $6.3 \mathrm{bc}$ & $6.3 \mathrm{bc}$ & 17.8 & 18.3 & $70.8 \mathrm{ab}$ & $70.5 \mathrm{c}$ & $11.5 \mathrm{ab}$ & $11.5 \mathrm{ab}$ & 4.6 & 4.5 & $6.2 \mathrm{bc}$ & $6.2 \mathrm{bc}$ \\
\hline $\mathrm{C}$ & $1.0-1.5$ & $6.6 \mathrm{ab}$ & $6.2 \mathrm{c}$ & 17.8 & 18.0 & $71.3 \mathrm{ab}$ & $70.6 \mathrm{bc}$ & $11.1 \mathrm{bc}$ & $11.6 \mathrm{a}$ & 4.6 & 4.6 & $6.4 \mathrm{ab}$ & $6.1 \mathrm{c}$ \\
\hline $\mathrm{C}$ & $0.5-1.0$ & $6.8 \mathrm{a}$ & $6.4 \mathrm{bc}$ & 17.9 & 18.1 & $71.5 \mathrm{a}$ & $70.6 \mathrm{bc}$ & $10.8 \mathrm{c}$ & $11.4 \mathrm{ab}$ & 4.6 & 4.5 & $6.7 \mathrm{a}$ & $6.2 \mathrm{bc}$ \\
\hline D & $1.5-2.0$ & $7.7 \mathrm{de}$ & $7.3 \mathrm{e}$ & $17.3 \mathrm{ab}$ & $17.8 \mathrm{a}$ & $73.1 \mathrm{c}$ & $72.3 \mathrm{~d}$ & $9.7 \mathrm{ab}$ & $10.1 \mathrm{a}$ & $4.8 \mathrm{~cd}$ & $4.6 \mathrm{~d}$ & $7.5 \mathrm{de}$ & $7.2 \mathrm{e}$ \\
\hline $\mathrm{D}$ & $1.0-1.5$ & $8.4 \mathrm{~b}$ & $7.9 \mathrm{~cd}$ & $16.9 \mathrm{bcd}$ & $17.0 \mathrm{bc}$ & $74.2 \mathrm{~b}$ & $73.5 \mathrm{bc}$ & $9.1 \mathrm{bc}$ & $9.6 \mathrm{ab}$ & $4.9 \mathrm{abc}$ & $4.9 \mathrm{bc}$ & $8.2 \mathrm{~b}$ & $7.7 \mathrm{~cd}$ \\
\hline $\mathrm{D}$ & $0.5-1.0$ & $8.9 \mathrm{a}$ & $8.1 \mathrm{bcd}$ & $16.4 \mathrm{~d}$ & $16.5 \mathrm{~cd}$ & $75.0 \mathrm{a}$ & $74.1 \mathrm{~b}$ & $8.7 \mathrm{c}$ & 9.5 & $5.1 \mathrm{a}$ & $5.1 \mathrm{ab}$ & $8.7 \mathrm{a}$ & $7.8 \mathrm{bcd}$ \\
\hline $\mathrm{D}$ & $<0.5^{\mathrm{g}}$ & $8.3 \mathrm{bc}$ & & $16.7 \mathrm{~cd}$ & & $74.2 \mathrm{~b}$ & & 9.2 & & $5.0 \mathrm{ab}$ & & $8.1 \mathrm{bc}$ & \\
\hline $\mathrm{E}$ & $>2.2$ & 6.1 & 6.2 & 20.3 & 19.0 & $68.4 \mathrm{bc}$ & $69.7 \mathrm{~b}$ & 11.4 & 11.5 & $3.9 \mathrm{~b}$ & $4.3 \mathrm{ab}$ & 6.0 & 6.1 \\
\hline $\mathrm{E}$ & $1.6-2.2$ & 6.5 & 6.2 & 19.4 & 21.3 & $69.7 \mathrm{~b}$ & $67.5 \mathrm{c}$ & 11.0 & 11.2 & $4.2 \mathrm{ab}$ & $3.7 \mathrm{~b}$ & 6.3 & 6.0 \\
\hline $\mathrm{E}$ & $1.0-1.6$ & 7.0 & 6.3 & 19.7 & 19.9 & $70.0 \mathrm{ab}$ & $69.0 \mathrm{bc}$ & 10.3 & 11.3 & $4.1 \mathrm{~b}$ & $4.1 \mathrm{~b}$ & 6.8 & 6.1 \\
\hline $\mathrm{E}$ & $0.4-1.0$ & 5.5 & 6.4 & 18.1 & 19.4 & 71.9 a & $69.6 \mathrm{~b}$ & 14.8 & 11.1 & $4.8 \mathrm{a}$ & $4.2 \mathrm{ab}$ & 5.4 & 6.3 \\
\hline $\mathrm{F}$ & $>2.8^{\mathrm{g}}$ & $7.7 \mathrm{e}$ & & $16.7 \mathrm{a}$ & & $73.5 \mathrm{~g}$ & & $9.8 \mathrm{a}$ & & $5.0 \mathrm{~b}$ & & $7.5 \mathrm{e}$ & \\
\hline $\mathrm{F}$ & $2.4-2.8$ & $8.1 \mathrm{de}$ & $7.8 \mathrm{e}$ & $16.2 \mathrm{abc}$ & $16.4 \mathrm{ab}$ & $74.3 \mathrm{ef}$ & .8 & $9.4 \mathrm{ab}$ & $9.8 \mathrm{a}$ & $5.2 \mathrm{ab}$ & $5.1 \mathrm{ab}$ & $7.9 \mathrm{cde}$ & $7.5 \mathrm{de}$ \\
\hline $\mathrm{F}$ & $2.0-2.4$ & $8.4 \mathrm{~cd}$ & $8.3 \mathrm{~cd}$ & $16.1 \mathrm{bc}$ & $16.1 \mathrm{bc}$ & 74.6 de & 74.5 de & $9.2 \mathrm{~b}$ & $9.4 \mathrm{~b}$ & $5.2 \mathrm{ab}$ & $5.2 \mathrm{ab}$ & $8.1 \mathrm{c}$ & $8.0 \mathrm{~cd}$ \\
\hline $\mathrm{F}$ & $1.6-2.0$ & $9.2 \mathrm{~b}$ & $8.6 \mathrm{c}$ & $16.1 \mathrm{bc}$ & $15.8 \mathrm{~cd}$ & $75.3 \mathrm{bc}$ & $75.1 \mathrm{~cd}$ & $8.5 \mathrm{c}$ & $9.1 \mathrm{~b}$ & $5.2 \mathrm{ab}$ & $5.3 \mathrm{ab}$ & $8.8 \mathrm{~b}$ & $8.3 \mathrm{c}$ \\
\hline $\mathrm{F}$ & $1.2-1.6$ & $9.5 \mathrm{ab}$ & $8.7 \mathrm{c}$ & $15.7 \mathrm{~cd}$ & $15.8 \mathrm{~cd}$ & $75.9 \mathrm{ab}$ & $75.1 \mathrm{~cd}$ & $8.3 \mathrm{c}$ & $9.1 \mathrm{~b}$ & $5.4 \mathrm{ab}$ & $5.3 \mathrm{ab}$ & $9.1 \mathrm{ab}$ & $8.3 \mathrm{c}$ \\
\hline $\mathrm{F}$ & $0.8-1.2$ & $9.7 \mathrm{ab}$ & $8.3 \mathrm{~cd}$ & $15.5 \mathrm{~d}$ & $15.3 \mathrm{~d}$ & $76.2 \mathrm{a}$ & $75.2 \mathrm{~cd}$ & $8.2 \mathrm{c}$ & $9.4 \mathrm{ab}$ & $5.5 \mathrm{a}$ & $5.5 \mathrm{a}$ & $9.3 \mathrm{ab}$ & $8.0 \mathrm{~cd}$ \\
\hline $\mathrm{F}$ & $0.4-0.8$ & $9.8 \mathrm{a}$ & $8.3 \mathrm{~cd}$ & $15.4 \mathrm{~d}$ & $16.1 \mathrm{bc}$ & $76.4 \mathrm{a}$ & $75.5 \mathrm{bc}$ & $8.2 \mathrm{c}$ & $9.4 \mathrm{ab}$ & $5.5 \mathrm{a}$ & $5.2 \mathrm{ab}$ & $9.4 \mathrm{a}$ & 7.9 cde \\
\hline $\mathrm{F}$ & $<0.4^{\mathrm{g}}$ & $9.5 \mathrm{ab}$ & & $15.5 \mathrm{~d}$ & & $76.0 \mathrm{ab}$ & & $8.4 \mathrm{c}$ & & $5.5 \mathrm{a}$ & & $9.0 \mathrm{ab}$ & \\
\hline
\end{tabular}

Each value is the mean value of three replicates

a Oleic acid \%/Linoleic acid \%

b Saturated fatty acid \%

c Monounsaturated fatty acid $\%$

d Polyunsaturated fatty acid \%

f Two mean values of the same hedgerow followed by the same small letter are not significantly different $(P \leq 0.05)$ according to Duncan's multiple range test

g In this layer the oil was extracted from the olives of both faces

309 ratio exhibited a similar behavior, whereas the variation of 310 PUFA content, where linoleic acid content is the main 311 component, showed an inverse tendency. Similarly, as the 312 content on palmitic acid was the most representative 313 among the different SAFA, the variation of the total con314 tent of them followed the same tendency than the content 315 of this fatty acid individually considered. So, in the 316 hedgerows D, F and I the total content of SAFA increased 317 with the height of the canopy layer. In contrast, the situa318 tion of SAFA content, placed in the denominator of the 319 UNFA/SAFA quotient, was determinant for the inverse tendency showed by the values of this formula (higher values in lower height layers), because the presence in the numerator of the addition of the contents on oleic and linoleic acids compensated both opposed tendencies. No significant differences between faces on fatty acid variables were ever found, comparing faces for each height layer. However, observing the values of these variables in the two faces of each height layer, almost systematically, the values of a determinate face are higher (Tables 4, 5, 6, 7). The statistical analysis of these variables, grouping the values of all the hedgerows tested according to their different

\begin{tabular}{|l|ll|} 
Journal : Large 11746 & Dispatch : 14-7-2011 & Pages : $\mathbf{1 1}$ \\
Article No. : $\mathbf{1 9 0 0}$ & $\square$ LE & $\square$ TYPESET \\
MS Code : JAOCS-11-0028 & $\sim_{\text {CP }}$ & $\checkmark$ DISK \\
\hline
\end{tabular}


Table 7 Fatty acid formulas of oils extracted from olives harvested at different layers in East-West hedgerows and, consequently, presenting two faces oriented North-South

\begin{tabular}{|c|c|c|c|c|c|c|c|c|c|c|c|c|c|}
\hline \multicolumn{2}{|c|}{ Fatty acid formula } & \multicolumn{2}{|c|}{$18: 1 / 18: 2$} & \multicolumn{2}{|l|}{ SAFA } & \multicolumn{2}{|l|}{ MUFA } & \multicolumn{2}{|l|}{ PUFA } & \multicolumn{2}{|c|}{ UNFA/SAFA } & \multicolumn{2}{|c|}{ MUFA/PUFA } \\
\hline Hedgerow & $\begin{array}{l}\text { Face } \\
\text { height }(\mathrm{m})\end{array}$ & North & South & North & South & North & South & North & South & North & South & North & South \\
\hline G & $1.5-2.0$ & $5.8^{\mathrm{a}}$ & 5.5 & 18.0 & 18.3 & 69.9 & 69.1 & 12.3 & 12.9 & 4.6 & 4.5 & 5.7 & 5.4 \\
\hline $\mathrm{G}$ & $1.0-1.5$ & 5.9 & 5.8 & 18.2 & 18.4 & 69.9 & 69.6 & 12.1 & 12.2 & 4.5 & 4.5 & 5.8 & 5.7 \\
\hline G & $0.5-1.0$ & 6.3 & 6.3 & 18.1 & 18.3 & 70.5 & 70.5 & 11.5 & 11.5 & 4.5 & 4.5 & 6.2 & 6.1 \\
\hline $\mathrm{H}$ & $1.5-2.0$ & 6.7 & 6.6 & 17.4 & 17.6 & 71.7 & 71.5 & 10.9 & 11.0 & 4.7 & 4.7 & 6.6 & 6.5 \\
\hline $\mathrm{H}$ & $1.0-1.5$ & 6.9 & 6.9 & 17.0 & 17.3 & 72.3 & 72.0 & 10.7 & 10.8 & 4.9 & 4.8 & 6.8 & 6.7 \\
\hline $\mathrm{H}$ & $0.5-1.0$ & 7.1 & 7.1 & 17.2 & 17.4 & 72.5 & 72.3 & 10.4 & 10.4 & 4.8 & 4.8 & 7.0 & 7.0 \\
\hline I & $>2.8$ & $9.0 \mathrm{hi}$ & $8.4 \mathrm{i}$ & $15.1 \mathrm{ab}$ & $15.6 \mathrm{a}$ & $75.9 \mathrm{fg}$ & $75.1 \mathrm{~g}$ & $8.9 \mathrm{ab}$ & $9.3 \mathrm{a}$ & $5.6 \mathrm{def}$ & $5.4 \mathrm{f}$ & $8.6 \mathrm{hi}$ & $8.1 \mathrm{i}$ \\
\hline I & $2.4-2.8$ & $9.4 \mathrm{gh}$ & $9.1 \mathrm{hi}$ & $14.6 \mathrm{bc}$ & $15.3 \mathrm{a}$ & 76.7 ef & $75.9 \mathrm{fg}$ & $8.6 \mathrm{~b}$ & $8.8 \mathrm{~b}$ & $5.8 \mathrm{cde}$ & $5.5 \mathrm{ef}$ & $8.9 \mathrm{gh}$ & $8.7 \mathrm{hi}$ \\
\hline I & $2.0-2.4$ & $10.2 \mathrm{f}$ & $9.9 \mathrm{fg}$ & $14.7 \mathrm{bc}$ & $14.5 \mathrm{bcd}$ & $77.3 \mathrm{de}$ & $77.3 \mathrm{de}$ & $8.0 \mathrm{c}$ & $8.2 \mathrm{c}$ & $5.8 \mathrm{cde}$ & $5.9 \mathrm{bcd}$ & $9.7 \mathrm{f}$ & $9.5 \mathrm{fg}$ \\
\hline I & $1.6-2.0$ & $11.0 \mathrm{de}$ & $10.6 \mathrm{ef}$ & $14.0 \mathrm{de}$ & $14.2 \mathrm{cde}$ & $78.4 \mathrm{bc}$ & $78.0 \mathrm{~cd}$ & $7.5 \mathrm{de}$ & $7.8 \mathrm{~cd}$ & $6.2 \mathrm{ab}$ & $6.0 \mathrm{abc}$ & $10.4 \mathrm{de}$ & $10.1 \mathrm{ef}$ \\
\hline I & $1.2-1.6$ & $12.0 \mathrm{bc}$ & $11.1 \mathrm{de}$ & $13.8 \mathrm{e}$ & $14.2 \mathrm{cde}$ & $79.2 \mathrm{ab}$ & $78.3 \mathrm{bcd}$ & $7.0 \mathrm{fgh}$ & $7.5 \mathrm{def}$ & $6.3 \mathrm{a}$ & $6.0 \mathrm{abc}$ & $11.3 \mathrm{bc}$ & $10.5 \mathrm{de}$ \\
\hline I & $0.8-1.2$ & $12.4 \mathrm{ab}$ & $11.4 \mathrm{~cd}$ & $13.6 \mathrm{e}$ & $14.0 \mathrm{cde}$ & $79.5 \mathrm{a}$ & $78.6 \mathrm{abc}$ & $6.8 \mathrm{gh}$ & $7.3 \mathrm{def}$ & $6.4 \mathrm{a}$ & $6.1 \mathrm{abc}$ & $11.7 \mathrm{ab}$ & $10.8 \mathrm{~cd}$ \\
\hline I & $0.4-0.8$ & $12.9 \mathrm{a}$ & $11.6 \mathrm{~cd}$ & $13.8 \mathrm{e}$ & $14.0 \mathrm{cde}$ & $79.5 \mathrm{a}$ & $78.7 \mathrm{abc}$ & $6.6 \mathrm{~h}$ & $7.2 \mathrm{efg}$ & $6.2 \mathrm{a}$ & $6.1 \mathrm{abc}$ & $12.1 \mathrm{a}$ & $10.9 \mathrm{~cd}$ \\
\hline
\end{tabular}

Each value is the mean value of three replicates

a Oleic acid \%/linoleic acid \%

b Saturated fatty acid \%

${ }^{\mathrm{c}}$ Monounsaturated fatty acid $\%$

${ }^{\mathrm{d}}$ Polyunsaturated fatty acid $\%$

${ }^{\mathrm{f}}$ Two mean values in the same hedgerow followed by the same small letter are not significantly different $(P \leq 0.05)$ according to Duncan's multiple range test

${ }^{g}$ In this layer the oil was extracted from the olives of both faces

orientation and pairing the values of the different face of each height layer using parametric (Paired Samples $t$-test) and non-parametric (Wilcoxon Signed Ranks and Signs tests) comparison tests confirmed this previous observation and found significant differences between the different faces of fruit growing in almost all the fatty acid-related variables tested (Table 8). Thus, comparing the results obtained between the faces East and West of the NorthSouth oriented hedgerows it was found that the oil extracted from the olives grown in the East face of the canopy presented significantly higher contents of oleic acid, 18:1/18:2, UNFA: SAFA ratio, and MUFA: PUFA ratio, and showed significantly lower palmitic (not according the Paired Samples $t$-test) and linoleic acid contents. In the same way, comparing the North and South faces of the East-West oriented hedgerows, significantly higher contents of oleic acid, 18:1/18:2, UNFA: SAFA ratio, and MUFA: PUFA ratio were found, whereas significantly lower contents of palmitic and linoleic acids were found in the oils extracted from the olives grown in the North face of these hedgerows. From a nutritional point of view a higher presence of MUFA in combination with a notable, but non excessive, presence of PUFA in the fatty acid composition of the oils is ideal for the human diet
[18]. The global statistical analysis confirmed that the highest layers presented significantly higher values of PUFA, and SAFA, but the significantly lowest MUFA, UNFA, 18:1/18:2, UNFA/SAFA and MUFA/PUFA values. Similarly, East-face produced oil with significantly higher MUFA, UNFA, UNFA/SAFA values, but lower PUFA and SAFA values than West face, but no significant differences between North and South faces or between the different hedgerow orientations were observed.

Sensory Analysis

No significant effect as a consequence of the different place of fruit growing in the canopy of an olive hedgerow was found on the sensory attributes in the oils (data not shown). Mean values of sensory attributes: olive fruit, bitterness and pungency of the oils were 2.0, 1.2 and 1.8 respectively. Furthermore, the presence of negative attributes was not detected in any of these oils. The sensory note of "Almond" was the most common among the oils tested, being present in 25 of a total of 34 different oils. Normally, this note is related with the oil extracted from middle ripe or ripe 'Arbequina' olives. The second sensory note in frequency (23 oils) was "banana", which indicates

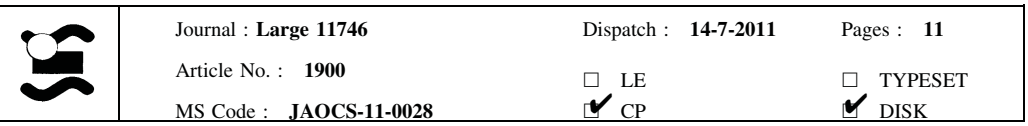


Table 8 Comparison between hedgerow faces on different fatty acids and related variables of oils extracted from olives harvested at different heights from North-South and East-West hedgerows

\begin{tabular}{|c|c|c|c|}
\hline \multirow[b]{2}{*}{ Pair of variables tested } & \multicolumn{3}{|c|}{ Significance level of different statistical comparison tests } \\
\hline & Paired samples $t$ test & Wilcoxon signed ranks test & Signs test \\
\hline Palmitic East-palmitic West ${ }^{\mathrm{a}}$ & 0.10 & $0.02 *$ & $0.03 *$ \\
\hline Palmitic North-palmitic South ${ }^{\mathrm{b}}$ & $0.00^{*}$ & $0.00 *$ & $0.00 *$ \\
\hline Oleic East-oleic West ${ }^{\mathrm{a}}$ & $0.00 *$ & $0.00 *$ & $0.00 *$ \\
\hline Oleic North-oleic South ${ }^{\mathrm{b}}$ & $0.00^{*}$ & $0.00 *$ & $0.00 *$ \\
\hline Linoleic East-linoleic West ${ }^{\mathrm{a}}$ & 0.10 & $0.00 *$ & $0.00 *$ \\
\hline Linoleic North-linoleic South ${ }^{\mathrm{b}}$ & $0.00^{*}$ & $0.00 *$ & $0.01 *$ \\
\hline Oleic/linoleic East-oleic/linoleic West ${ }^{\mathrm{a}}$ & $0.00^{*}$ & $0.00 *$ & $0.00 *$ \\
\hline UNFA/SAFA East-UNFA/SAFA West $^{\mathrm{a}}$ & $0.05^{*}$ & $0.02 *$ & $0.05 *$ \\
\hline MUFA/PUFA East-MUFA/PUFA West $^{\mathrm{a}}$ & $0.00^{*}$ & $0.00 *$ & $0.00 *$ \\
\hline Oleic/linoleic North-oleic/linoleic South ${ }^{\mathrm{b}}$ & $0.00^{*}$ & $0.00 *$ & $0.00 *$ \\
\hline UNFA/SAFA North-UNFA/SAFA South ${ }^{\mathrm{b}}$ & $0.00^{*}$ & $0.00 *$ & $0.00 *$ \\
\hline MUFA/PUFA North-MUFA/PUFA South ${ }^{\mathrm{b}}$ & $0.01 *$ & $0.00 *$ & $0.00 *$ \\
\hline
\end{tabular}

* Significant effect $(P \leq 0.05)$ of the factor considered for this variable

${ }^{\text {a }}$ North-South (21 different layers)

b East-West (12 different layers)

low-ripe fruit origin. The sensory note "apple" was present in 18 oils, being the third frequency in the ranking of sensory notes. This attribute is characteristic of oils extracted from olives with a low level of maturity. The fourth position was occupied by two notes with the same frequency of detection (13 oils): "mature tomato" and "green leaf", which are characteristic of the oils extracted from ripe and unripe olives, respectively. The sensory note "grass", clearly indicative of the unripe fruit used for oil extraction, also achieved a relevant frequency of detection (11 oils). Finally, other sensory notes such as: "green tomato" (5 oils), "tea infusion" ( 2 oils), "artichoke" (1 oil) and "excessively mature fruit" (1 oil) were also detected. The analysis by $\chi^{2}$, using contingency tables, of the distribution of these sensory notes among the oils extracted established that it was not significantly affected by the different canopy height layer or face, from where the olives were harvested (data not shown).

\section{Tocopherol and Phenol Contents}

Among the different tocopherol molecules found in the oils analyzed only the $\gamma$-tocopherol content of the oil was affected by the different position of the fruit in the canopy (data not shown). The concentration of this molecule proved to be significantly higher in the lower height layer of both hedgerows tested (F and I). However, this fact has a scarce nutritional meaning, because the content of $\gamma$-tocopherol $(2.9 \mathrm{mg} / \mathrm{kg})$ is ridiculous in comparison to the content of $\alpha$-tocopherol $(284.0 \mathrm{mg} / \mathrm{kg})$ which was not affected by the fruit position in the canopy.
The height layer of the fruit growing in the olive hedgerow was the most determinant factor for the contents in the oils of the most representative phenol molecule groups (Fig. 1). Thus, in both hedgerows tested, considered independently or in a group, the oil extracted from fruit harvested from the higher height layer had significantly higher contents of $p$-HPEA-EDA, 3.4 DHPA-EA, orthodiphenols, secoiridoid derivatives, and total phenols. This fact coincided with the significantly higher stability observed in the oils extracted from olives harvested in the higher height layers of the canopy (Tables 2,3). The higher presence of these compounds is probably strongly related with this fact. Furthermore, the oils extracted from the hedgerow F (North-South orientation) olives, independently of its position in the canopy, showed higher contents of these phenol molecules than the ones extracted from hedgerow I (East-West orientation) fruits. However, no significant effect was detected as a consequence of the different face in each hedgerow tested. This finding encourages the orientation North-South rather than EastWest for the olive hedgerow design to obtain oils enriched in these natural antioxidants.

\section{Conclusions}

The position of the fruit in the canopies in an olive hedgerow may be a determinant factor for some parameters used to evaluate the commercial and nutritional quality of the virgin oil, such as stability against oxidation, fatty acid composition or phenol content, while sensory attributes

\begin{tabular}{|l|lll|}
\hline & Journal : Large 11746 & Dispatch : $\mathbf{1 4 - 7 - 2 0 1 1}$ & Pages : 11 \\
& Article No. : $\mathbf{1 9 0 0}$ & $\square \mathrm{LE}$ & $\square$ \\
MS Code : JAOCS-11-0028 & $\checkmark_{\mathrm{CP}}$ & $\checkmark$ TYSESET \\
\hline
\end{tabular}


(a)

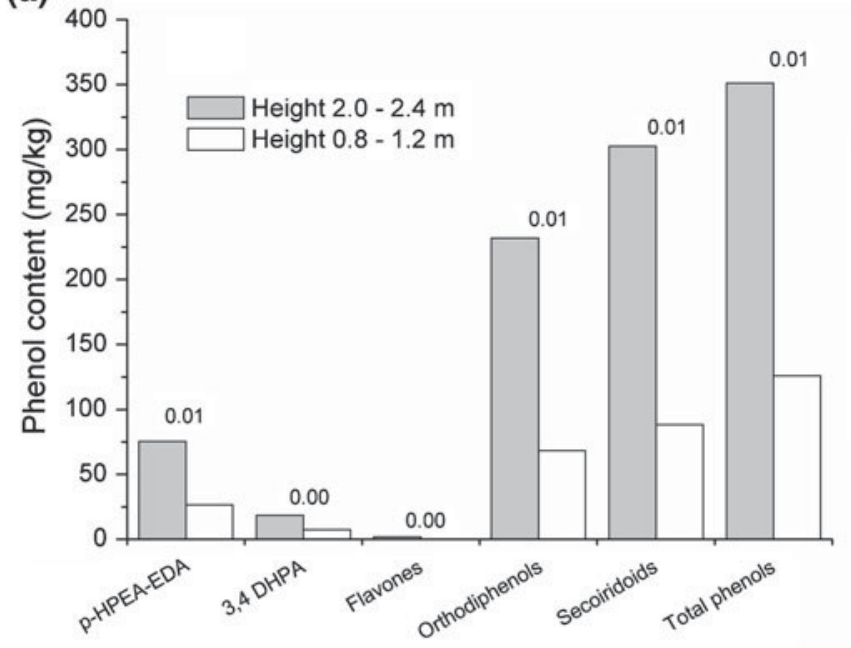

(c)

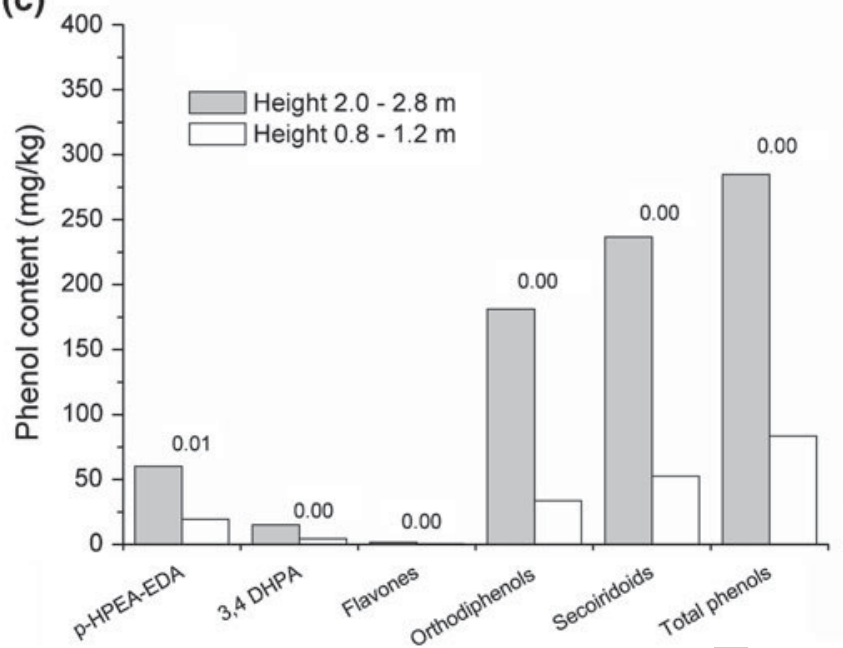

Fig. 1 Phenol contents $(\mathrm{mg} / \mathrm{kg})$ of oils extracted from olives harvested at two different height layers in North-South and EastWest oriented hedgerows, considering the following factors: a different height layer in North-South oriented hedgerow, $\mathbf{b}$ different height layer in East-West oriented hedgerow, $\mathbf{c}$ different height layers in obtained by reducing the row distance and increasing (b)

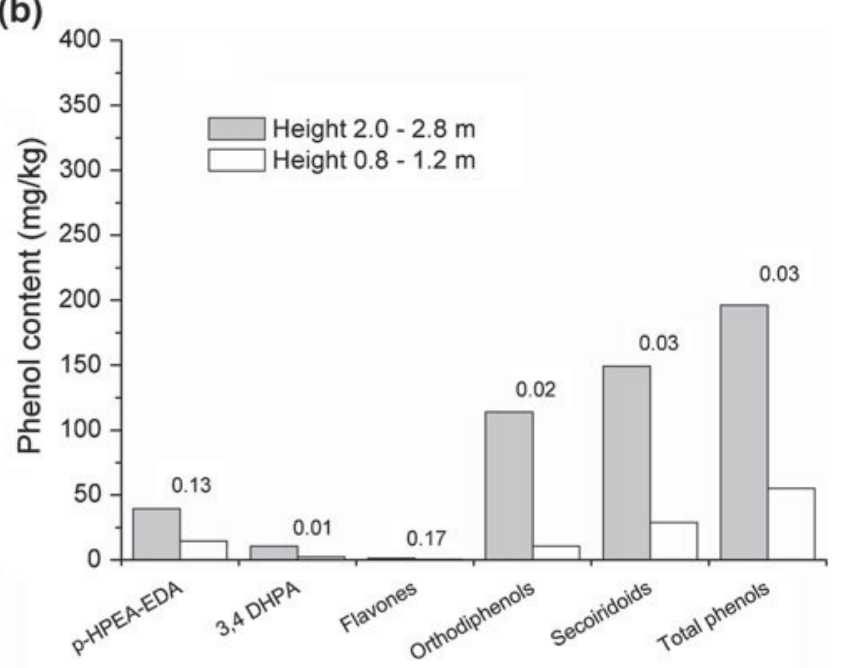

(d)

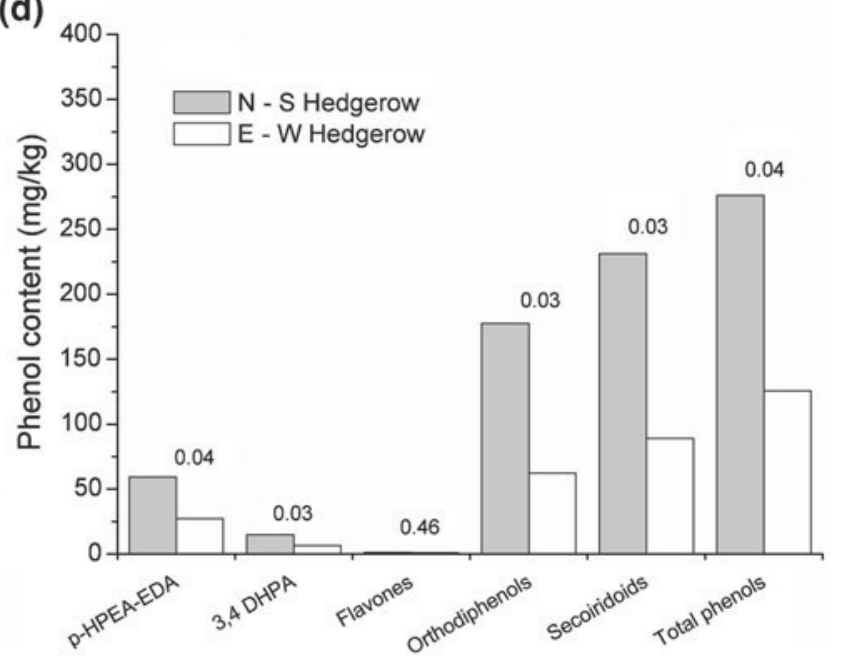

both North-South and East-West oriented hedgerows, and d different oriented hedgerows, considering both height layers. In each variable is assigned the probability of no effect due to the factor considered, according to one way ANOVA test

height and width of hedgerow. Hedgerow orientation may 449 affect oil quality. North-South orientation may produce virgin olive oil richer in phenol contents and the East face of this orientation may produce higher concentrations in oleic fatty acid.

Acknowledgments We gratefully acknowledge Jacinto Cabetas from El Carpio de Tajo, Antonio Capitán from Écija, Agrícola La Veguilla from Puebla de Montalbán for access to the olive orchards where this research was conducted and Maximiliano Arteaga (from ARCO), Ignacio San Juan and Esther Alonso (from official panel test of Comunidad de Madrid) for oil testing and Ana Centeno, Angela Rodríguez, Beatriz Somoza, Enrique Vivas, Mercedes Ortí for helping in olive collection and oil extraction and Javier García for statistical analysis. This research was supported by the Universidad Politécnica de Madrid and the Comunidad de Madrid (Project M0800204112).

\begin{tabular}{|llll|} 
Journal : Large 11746 & Dispatch : 14-7-2011 & Pages : 11 \\
Article No. : 1900 & $\square$ LE & $\square$ TYPESET \\
MS Code : JAOCS-11-0028 & $\checkmark_{\text {CP }}$ & $\checkmark$ DISK \\
\hline
\end{tabular}




\section{References}

1. Morettini A (1972) Olivicoltura. Ramo Editoriale Degli Agricoltori, Rome

2. Acebedo MM, Cañete ML, Cuevas J (2000) Processes affecting fruit distribution and its quality in the canopy of olive trees. Adv Hortic Sci 14:169-175

3. Gómez-del-Campo M, Centeno A, Connor DJ (2009) Yield determination in olive hedgerow orchards. I. yield and profiles of yield components in north-south and east-west oriented hedgerows. Crop Pasture Sci 60:434-442

4. Tombesi A, Cartechini A (1986) L'effetto dell' ombreggiamento della chioma sulla differenziazione delle gemme a fiore dell' olivo. Rivista Ortoflorofrutticoltura Italiana 70:277-285

5. Connor DJ, Centeno A, Gómez-del-Campo M (2009) Yield determination in olive hedgerow orchards. II. Analysis of radiation and fruiting profiles. Crop Pasture Sci 60:443-452

6. Yousfi K, Cert RM, García JM (2006) Changes in quality and phenolic compounds of virgin olive oils during objectively described fruit maturation. Eur Food Res Technol 223:117-124

7. Izquierdo NG, Aguirrezábal LAN, Andrade FH, Geroudet C, Valeninuz O, Pereyra M (2009) Intercepted solar radiation affects oil fatty acid composition in crop species. Field Crops Res 114:66-74

8. Martinez JM, Muñoz E, Alba J, Lanzón A (1975) Report about the use of the "Abencor" analyzer. Grasas y Aceites 26:379-385

9. Annexes II and IX in Official Journal European Communities (1991) n. L. 248 of 5 September, Regulation EEC/2568/91)
10. Laübli W, Bruttel PA (1986) Determination of the oxidative stability of fats and oils by the Rancimat method. J Am Oil Chem Soc 63:792-794

11. Mancha M, Sánchez J (1981) Incorporation of free fatty acids into acyltthioesters and lipids of developing sunflower seeds. Phytochemistry 20:2139-2142

12. IUPAC (1992) Standard method for the analysis of oils, fats, derivatives. Method 2432, 7th edn. Pergamon Press, Oxford

13. Mateos R, Espartero JL, Trujillo M, Rios JJ, León-Camacho M, Alcudia F, Cert A (2001) Determination of phenols, flavones, and lignans in virgin olive oils by solid-phase extraction and highperformance liquid chromatography with diode array ultraviolet detection. J Agric Food Chem 49:2185-2192

14. García JM, Seller S, Pérez-Camino MC (1996) Influence of fruit ripening on olive oil quality. J Agric Food Chem 44:3516-3520

15. Ayton J, Maile RJ, Haigh A, Tronson D, Conlan D (2007) Quality and oxidative stability of Australian olive oil according to harvest date and irrigation. J Food Lipids 1:138-156

16. Damak N, Bouaziz M, Ayadi M, Sayadi S, Damak M (2008) Effect of the maturation process on the phenolic fractions, fatty acids, and antioxidant activity of the Chetoui olive fruit cultivar. J Agric Food Chem 56:1560-1566

17. Menz G, Vriesekoop F (2010) Physical and chemical changes during the maturation of Gordal Sevillana olives (Olea europaea L., cv. Gordal Sevillana). J Agric Food Chem 58:4934-4938

18. Ganz TR, Harris D, Abbott LK, Kailis SG (2002) Organoleptic and nutritional quality of olive oil from the south-western region of Australia. Adv Hortic Sci 16:267-272

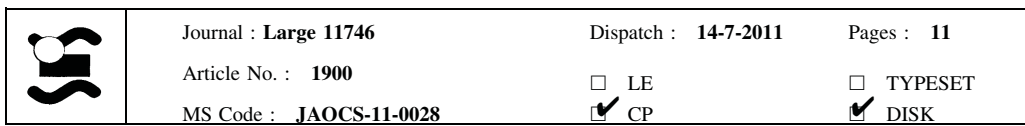

